\title{
Advances in the understanding of delayed cerebral ischaemia after aneurysmal subarachnoid haemorrhage [version 1; peer
} review: 4 approved]

\author{
Liam Flynn, Peter Andrews
}

Centre for Clinical Brain Sciences, University of Edinburgh, Edinburgh, UK

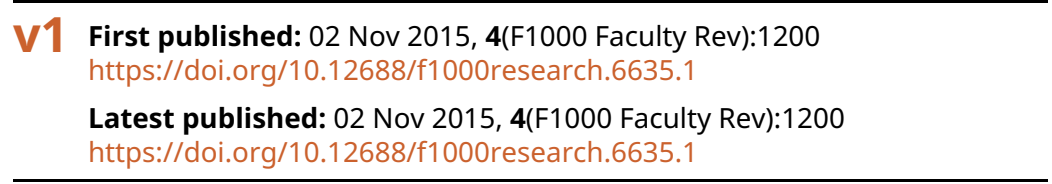

\section{Abstract}

Delayed cerebral ischaemia has been described as the single most important cause of morbidity and mortality in patients who survive the initial aneurysmal subarachnoid haemorrhage. Our understanding of the pathophysiology of delayed cerebral ischaemia is meagre at best and the calcium channel blocker nimodipine remains the only intervention to consistently improve functional outcome after aneurysmal subarachnoid haemorrhage. There is substantial evidence to support cerebral vessel narrowing as a causative factor in delayed cerebral ischaemia, but contemporary research demonstrating improvements in vessel narrowing has failed to show improved functional outcomes. This has encouraged researchers to investigate other potential causes of delayed cerebral ischaemia, such as early brain injury, microthrombosis, and cortical spreading depolarisation. Adherence to a common definition of delayed cerebral ischaemia is needed in order to allow easier assessment of studies using multiple different terms. Furthermore, improved recognition of delayed cerebral ischaemia would not only allow for faster treatment but also better assessment of interventions. Finally, understanding nimodipine's mechanism of action may allow us to develop similar agents with improved efficacy.

Keywords

Cerebral ischaemia, subarachnoid, haemorrhage ,
Open Peer Review

$\begin{array}{rrrr}\text { Approval Status } & \checkmark \\ 1 & 2 & 3 & 4\end{array}$

version 1

02 Nov 2015

Faculty Reviews are review articles written by the prestigious Members of Faculty Opinions. The articles are commissioned and peer reviewed before publication to ensure that the final, published version is comprehensive and accessible. The reviewers who approved the final version are listed with their names and affiliations.

1. Kyle Pattinson, John Radcliffe Hospital, Oxford, UK

Matthew Rowland, John Radcliffe Hospital, Oxford, UK

2. Stephan Mayer, Mount Sinai Medical Center, New York, New York, USA

3. Michael N. Diringer, Washington University School of Medicine, St. Louis, USA

4. Nikolaus Plesnila, University of Munich Medical Center, Munich, Germany Any comments on the article can be found at the 
end of the article.

Corresponding author: Liam Flynn (Imc.flynn@gmail.com)

Competing interests: The authors declare that they have no competing interests.

Grant information: The author(s) declared that no grants were involved in supporting this work.

Copyright: ( $) 2015$ Flynn L and Andrews P. This is an open access article distributed under the terms of the Creative Commons

Attribution License, which permits unrestricted use, distribution, and reproduction in any medium, provided the original work is properly cited.

How to cite this article: Flynn $L$ and Andrews $P$. Advances in the understanding of delayed cerebral ischaemia after aneurysmal subarachnoid haemorrhage [version 1; peer review: 4 approved] F1000Research 2015, 4(F1000 Faculty Rev):1200 https://doi.org/10.12688/f1000research.6635.1

First published: 02 Nov 2015, 4(F1000 Faculty Rev):1200 https://doi.org/10.12688/f1000research.6635.1 


\section{Introduction}

Aneurysmal subarachnoid haemorrhage (aSAH) has an incidence of 6-11 per 100,000 people per year and accounts for only $5 \%$ of all strokes ${ }^{1-4}$. Despite this, aSAH is the cause of one third of all strokerelated years of potential life lost before the age of $65^{5}$. Approximately $70 \%$ of all people with aSAH will either die or require help with activities of daily living at six months after the initial injury ${ }^{5}$. The mean age of onset of aSAH is 55 years and, when combined with its poor morbidity and mortality, it causes an enormous socioeconomic burden ${ }^{6,7}$. The significant morbidity attached to aSAH can be attributed to rebleeding, delayed cerebral ischaemia (DCI), hydrocephalus, and other medical complications, despite successful treatment of the ruptured aneurysm. Of these complications, DCI is the most important cause of morbidity and mortality in patients who survive the ruptured aneurysm ${ }^{5,8,9}$. Between days 3 and 10 after the initial aSAH, 30-40\% of patients will suffer DCI and half of these will have a poor outcome $e^{5,10,11}$.

Our understanding of DCI is meagre at best. Conventionally, DCI was thought of as a neurological deficit observed at least three days after aSAH with radiological confirmation of large vessel narrowing and was often termed "vasospasm". However, more contemporary articles question whether the relationship between angiographic cerebral vessel narrowing and neurological outcome is associative rather than causative and have highlighted the possibility of a multifactorial aetiology ${ }^{12-15}$. One of the problems with the disease and research surrounding DCI is the terminology applied. Terms include DCI, delayed ischaemic neurological deficit (DIND), delayed neurological deficit, secondary cerebral ischaemia, and vasospasm. In 2010, a consensus statement was issued defining DCI as a focal neurological impairment or decrease of $\geq 2$ points on the Glasgow Coma Scale which lasts for $\geq 1$ hour, is not apparent immediately after aneurysm occlusion, and cannot be attributed to other causes by means of clinical assessment, blood tests, or imaging ${ }^{16}$. The Neurocritical Care Society's consensus definition was similar for DCI and also defined vasospasm as radiological evidence of cerebral vessel narrowing with corresponding neurology ${ }^{17}$.

\section{Cerebral artery narrowing}

Over six decades ago, cerebral vessel narrowing was demonstrated by angiography after aSAH ${ }^{18}$. A decade later, a link was found between cerebral vessel narrowing and focal neurology ${ }^{19}$. Then in the late 1970s, it appeared that vessel narrowing was not only localised to the vascular territory of the aneurysmal bleed but also proportional to blood load and occurred between days 3 and 12 after the aSAH ${ }^{20,21}$. More contemporary authors found the onset of vessel narrowing started on day 3, was maximal by days 6-10, and lasted for up to two weeks ${ }^{22-24}$. The density, duration and volume of subarachnoid blood are key predictors of vessel narrowing ${ }^{21,25}$. Narrowing of cerebral arteries may cause a reduction in cerebral blood flow distal to the constricted vessel and contribute to secondary ischaemia ${ }^{26}$. The cause of vessel narrowing after aSAH is unclear but is thought to involve oxyhaemoglobin release, an inflammatorymediated response, decreased nitric oxide levels, and an increased concentration of endothelin-1 (ET-1) ${ }^{14}$.

\section{Oxyhaemoglobin}

Oxyhaemaglobin induces cerebral artery vasoconstriction in vitro and in vivo in primates, which is not seen with methaemoglobin or bilirubin $^{27-29}$. It is thought that oxyhaemoglobin decreases the production of prostacyclin and increases prostaglandin E2 in vessel walls, thereby causing vasoconstriction. It can also inhibit endothelial-dependent relaxation. The oxidation of oxyhaemoglobin to methaemoglobin, which occurs spontaneously, causes lipid peroxidation and vasoconstriction $^{30}$. It is plausible that oxyhaemoglobin causes vasoconstriction by some or all of these mechanisms but attempts at modulating them have not completely reversed vessel narrowing or, importantly, improved outcomes.

\section{Nitric oxide}

Nitric oxide, which is responsible for the relaxation of vascular smooth muscle cells, appears to be depleted after aSAH. This may be due to a number of reasons, one of which is that nitric oxide is scavenged by haemoglobin, released during the breakdown of subarachnoid blood, due to nitric oxide's high affinity for haemoglobin ${ }^{31,32}$. In addition to this, the production of nitric oxide may also be decreased due to the down-regulation of endothelial and neuronal nitric oxide synthase, which occurs in spastic arteries after aSAH ${ }^{33-35}$. Both of these mechanisms will lead to a decrease in the bioavailability of nitric oxide, which is then unable to counteract the effects of the vasoconstrictor ET- ${ }^{36}$. Furthermore, exogenous donors of nitric oxide, such as sodium nitroprusside and nitroglycerin, although associated with systemic side effects, have been shown to ameliorate cerebral artery narrowing ${ }^{37,38}$. In addition to the hypotension seen with these exogenous donors, there is also a concern that exposing nitric oxide to oxyhaemoglobin and deoxyhaemoglobin will lead to the formation of methaemoglobin, S-nitrosohaemoglobin and ferrous-nitrosyl-haemoglobin ${ }^{33}$. Interestingly, Kida et al. note in their comprehensive review that inhaled nitric oxide acts as a selective pulmonary vasodilator and avoids the hypotension seen with intravenous administration. Animal studies have demonstrated a reduction in ischaemia-reperfusion injuries after nitric oxide inhalation in extrapulmonary organs after cardiac injury. These have also been supported by proof-of-concept human trials ${ }^{39}$. The research discussed is used to support post-cardiac arrest ischaemia but Garry et al. also encourage further investigation of nitric oxide as a treatment of secondary brain injury in their review with reference to aSAH ${ }^{40}$.

\section{Endothelin}

Endothelin is key to maintaining the vascular tone of blood vessels, with ET-1 being the most potent endogenous activator of vasoconstriction. The amount of ET-1 in serum and plasma increases within minutes after the aSAH and peaks around days 3-4, the time at which DCI starts to occur. There also appears to be an excessive release of ET-1 by astrocytes around the time of onset of ischaemic symptoms $^{41,42}$. ET-1 concentrations appear consistently elevated in patients with DCI. However, there are conflicting reports of ET-1 concentrations within the normal range in patients with radiological evidence of cerebral artery narrowing who do not have $\mathrm{DCI}^{43-45}$. Authors have questioned whether increased ET-1 marks ischaemic 
damage rather than arterial vessel narrowing in $\mathrm{DCI}^{14}$. Therefore, there are a number of different mechanisms that could be contributing to the arterial narrowing commonly seen after aSAH.

\section{Alpha calcitonin gene-related peptide}

Alpha calcitonin gene-related peptide (CGRP) is an endogenous neuropeptide and a potent vasodilator. CGRP exhibits its vasodilating properties by two mechanisms: one is nitric oxide and endothelium-dependent and the other is cyclic adenosine monophosphate mediated and is endothelium-independent ${ }^{46}$. Endogenous CGRP appears to be released, and is subsequently depleted, after aSAH to combat cerebral vasoconstriction which has led to the theory that exogenous CGRP may be beneficial in managing DCI ${ }^{47-49}$. Because CGRP can act independently of endothelial cells, which are morphologically damaged after aSAH, it may be successful in treating DCI. A number of animal studies and three human trials have investigated the effect of CGRP on cerebral arteries after aSAH. All animal studies appear to show either a reversal or improvement in cerebral artery narrowing ${ }^{46}$. The largest human trial, the European CGRP in aSAH study, demonstrated little improvement in morbidity or mortality from intravenous administration but noted that systemic side effects, such as hypotension, were limiting and suggested that intrathecal administration may be more beneficial, as endogenous CGRP acts on the abluminal side of vessel walls ${ }^{50}$. A trial investigating the effect of CGRP after intrathecal administration is still awaited.

\section{Radiological evidence}

An often-cited argument against cerebral vasoconstriction being a causative factor of DCI is that, whilst up to $70 \%$ of patients demonstrate cerebral vessel narrowing on angiography, only $40 \%$ of these will manifest neurological deficits and only $30 \%$ develop DCI $^{51-54}$. However, it must be acknowledged that even the consensus definition of DCI provided in the introduction has its limitations ${ }^{16}$. Patients with poor grade aSAH (World Federation of Neurosurgical Societies Grades IV and V), the group of patients most likely to develop DCI, are often sedated and mechanically ventilated and are particularly difficult to assess clinically ${ }^{55}$. Therefore, it is likely that we are under-diagnosing and under-treating DCI in this group of patients. Furthermore, it may be that the degree of large cerebral vessel narrowing does not correlate well with symptom severity $^{26}$.

Following a review of current tests available for the diagnosis of delayed cerebral ischaemia, Rodriguez et al. advise clinical examination and transcranial Doppler (TCD) in the screening and diagnosis of "vasospasm". The authors reserve multi-modal magnetic resonance imaging (MRI) and computed tomography (CT) for specific situations, and acknowledge digital subtraction angiography (DSA) as the gold standard for diagnosis (Figure 1) ${ }^{56}$. Rabinstein et al. found that TCD and angiogram demonstrating cerebral vessel narrowing (termed vasospasm) only had a positive predictive value of $67 \%$ for cerebral infarction on $\mathrm{CT}^{8}$. We would expect this to be higher if cerebral vessel narrowing was the primary cause of DCI. Rates of cerebral infarction in patients with evidence of cerebral vessel narrowing range between 24 and $35 \%$ using $\mathrm{CT}^{57,58}$, but have been found to be as high as $81 \%$ in some studies using $\mathrm{MRI}^{59}$. In addition to this poor correlation between cerebral vessel narrowing

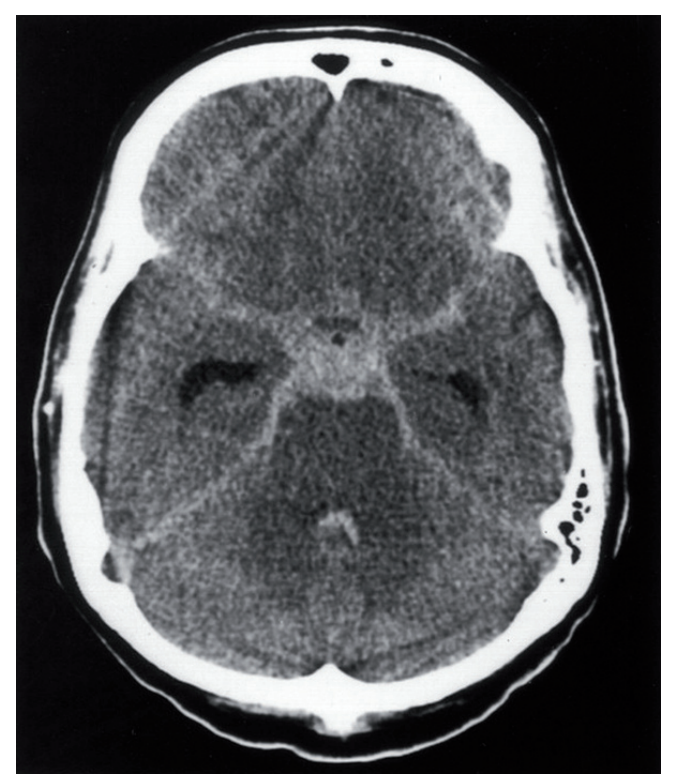

Figure 1. CT image of subarachnoid haemorrhage. Non-contrast CT scan of brain showing subarachnoid haemorrhage in classical "star sign" distribution with blood distributed along basal vessels.

and infarction, there is clinical evidence that up to $25 \%$ of delayed infarcts on CT are not in the same territory as the vessel narrowing, or are found in patients that did not demonstrate vessel narrowing at all ${ }^{60-62}$. Rabinstein et al. note that TCD and angiogram only agreed on the diagnosis of "vasospasm" in $73 \%$ of cases and so it could be that vessel narrowing simply wasn't identified in patients who were later found to have evidence of infarcts on $\mathrm{CT}^{8}$. Despite these conflicting messages, clinical studies do report that those patients with radiological evidence of cerebral vessel narrowing are at greater risk of $\mathrm{DCI}^{62,63}$.

Herz et al. directly visualised pial artery constriction after application of blood or microtrauma to pial arteries in animal studies ${ }^{64}$. Further in vitro research has suggested that constriction of intraparenchymal arterioles occurs after aSAH and may contribute to $\mathrm{DCI}^{65}$. Maximal luminal narrowing has been seen between days 3 and 7 and repeated in vivo in mouse studies. The correlation between decreased regional cerebral blood flow and microvascular constriction appears stronger than that seen with large vessel narrowing ${ }^{65-67}$. Uhl et al. identified constriction of small vessels in surgical patients within the first 72 hours after aSAH by spectral imaging, and Pennings et al. later directly observed cerebral arterioles contracting after aSAH ${ }^{68,69}$. Therefore, it may be that vessel narrowing is consistently occurring with DCI but that we are not visualising it because it is microvascular and not readily visible on catheter angiography or TCD ${ }^{56}$.

CT perfusion scanning (CTP) may provide haemodynamic evidence to support the diagnosis of DCI. Dankbaar et al. evaluated the diagnostic value of CTP for DCI and reported $84 \%$ sensitivity, $79 \%$ specificity, and $88 \%$ positive predictive values ${ }^{70}$. Sanelli et al. found that more CTP deficits occurred in patients with DCI than in those 
without $^{71}$. Dankbaar et al. later suggested that patients with DCI exhibit worse cerebral perfusion (measured on CTP) than patients without DCI even before focal signs occurred. Encouragingly, they demonstrated partial recovery in areas of poor perfusion, suggesting that DCI could be partly reversible ${ }^{72}$. However, Killeen et al. concluded from their retrospective comparative study that CTP and DSA had similar test characteristics for identifying DCI in aSAH patients ${ }^{73}$.

\section{Endothelin-antagonists}

A shift in theory from cerebral vessel narrowing to a multifactorial aetiology occurred after the CONSCIOUS trials and a recent meta-analysis of pharmacological treatments for delayed cerebral ischaemia ${ }^{74-76}$. The meta-analysis demonstrated that, despite a reduction of cerebral vessel narrowing, no statistically significant effect on poor outcome was observed ${ }^{74}$. However, the authors note that the dissociation between a reduction in cerebral vessel narrowing but not poor outcomes could result from methodological problems, sample size, and insensitivity of outcome measures, in addition to a multifactorial aetiology of DCI. The CONSCIOUS trials were multicentre randomised controlled trials (RCT) investigating the effect of clazosentan, an endothelin-A (ET-A) antagonist, on "vasospasm" after aSAH. The first of these trials, CONSCIOUS-1, demonstrated that, despite a significant reduction in angiographic cerebral vessel narrowing, there was little evidence to support its use to improve morbidity and mortality and it was associated with increased rates of pulmonary complications, hypotension and anaemia ${ }^{76}$. CONSCIOUS-2 demonstrated no benefit from clazosentan in patients treated with surgical clipping, which led to the early termination of the trial ${ }^{75}$. Laban et al. recently published a review of animal studies investigating endothelin receptor antagonists after experimental aSAH and found no improvement in functional outcomes ${ }^{77}$. Perhaps more importantly, the review described insufficient animal data supporting endothelin receptor antagonists to warrant progression to a human trial. The authors also suggest that cerebral artery diameter, or "vasospasm", is not a clinically relevant outcome measure in experimental aSAH studies ${ }^{77}$.

The example of clazosentan appears to provide evidence that cerebral artery narrowing is not the sole cause of DCI. However, there is conflicting evidence as more invasive methods of reducing vessel narrowing can improve outcomes (Figure 2). Kimball et al. reviewed 49 articles relating to interventional techniques to treat "vasospasm". A total of 24 of the 27 publications $(1,028$ patients) reporting the use of transluminal balloon angioplasty noted an improvement in vessel diameter and neurological deficits. Twelve case series reported good angiographic and clinical results for patients who received papaverine (a vasodilator) administered approximate to the site of vessel narrowing ${ }^{78}$. Both techniques were associated with significant side effects and the quality of the studies was reported as very low to moderate (based upon the GRADE classification system ${ }^{79}$. Nevertheless, the review does provide evidence that cerebral artery narrowing is likely to be strongly involved in the pathology of DCI.

\section{Nimodopine}

The calcium channel antagonist nimodipine is the only proven intervention to reduce the incidence of DCI and improve outcomes after aSAH. Nimodopine was initially investigated as a vasodilator in the hope that it would aid post-ischaemic reperfusion, as it was thought that an increase in calcium in vascular smooth muscle cells led to "vasospasm" 80,81 . In 1989, the British Aneurysm Nimodipine Trial subsequently demonstrated a significant reduction in cerebral infarction rates and improved neurological outcomes at three months after aSAH ${ }^{82}$. A Cochrane review in 2007 concurred with these findings but noted that the supporting evidence was based mainly on one large study. This led to oral nimodipine becoming standard care for patients after aSAH ${ }^{83}$. Interestingly, the review found no statistically significant results to support the use of other calcium antagonists, magnesium sulphate, or intravenous administration of nimodipine.

Magnesium sulphate is a non-competitive inhibitor of calcium channels and has vasodilatory and neuroprotective properties, similar to nimodipine. Hypomagnesaemia is common in patients after aSAH, appears to be proportional to the severity of the bleed, and is predictive of $\mathrm{DCI}^{84}$. Magnesium sulphate has also been shown to reduce cerebral artery narrowing and the size of ischaemic lesions after aSAH in animal models ${ }^{85}$. However, the Neurocritical Care Society guidelines advise against the routine administration of magnesium in patients with aSAH ${ }^{17}$. This is supported by data from the intravenous magnesium sulphate for aneurysmal subarachnoid haemorrhage (IMASH) and MASH-2 trials and a recent meta-analysis demonstrating no beneficial effect of magnesium in this group of patients ${ }^{86-88}$. A post hoc analysis of the IMASH trial reported an association between high plasma levels of magnesium and worse clinical outcomes ${ }^{89}$.

In summary, one calcium channel antagonist, nimodipine, has been shown to be effective in the prevention and treatment of DCI after aSAH whilst other calcium channel antagonists and a non-competitive inhibitor of calcium channels appear to have little effect on, or worsen outcomes.

It remains unclear how nimodipine exerts its neuroprotective effects but its action seems independent of any effect on large vessel narrowing ${ }^{90,91}$. It was thought that nimodipine may exert its effect by stopping calcium influx at a neuronal level, but no beneficial effect has been seen from administration in patients after ischaemic stroke or traumatic brain injury ${ }^{92-94}$. In addition to this, a recent systematic review found no benefit from nimodipine after traumatic $\mathrm{SAH}$, suggesting that the mechanism of action of nimodipine is unique to $\mathrm{aSAH}^{95}$. Nimodipine has two properties that it does not share with other calcium channel antagonists. Firstly, it increases endogenous fibrinolytic activity, which may reduce the incidence of microthrombosis ${ }^{96}$. Secondly, it antagonises cortical spreading ischaemia in rats, which may be one of the culprits in DCI and is discussed in further detail below ${ }^{97}$. 

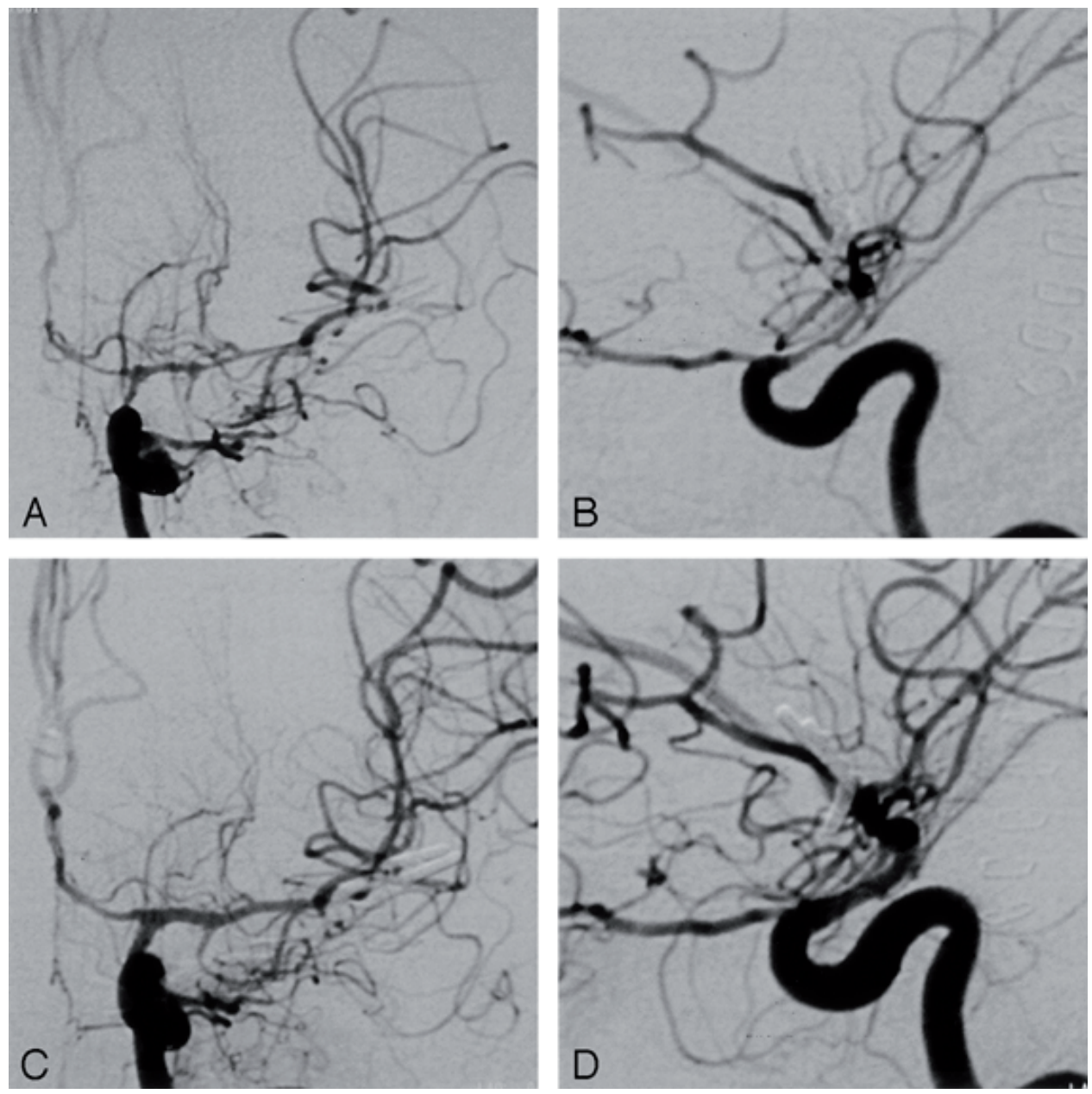

Figure 2. Angiograms demonstrating cerebral vessel narrowing after subarachnoid haemorrhage. A and $\mathbf{B}$ : Anteroposterior (A) and lateral (B) angiograms of the left internal carotid artery demonstrate vessel narrowing at the level of the carotid siphon, the terminal internal carotid artery, the A1 segment of the anterior cerebral artery and the middle cerebral artery. C and $\mathbf{D}$ : Anteroposterior (C) and lateral (D) angiograms obtained after intra-arterial injection of nimodipine.

\section{Contemporary hypotheses \\ Early brain injury}

Early brain injury (EBI) refers to damage to the brain in the first 72 hours after the haemorrhage. There are a number of pathophysiological events in this time period that could influence later complications, such as DCI, and much of our understanding is derived from experimental data. One of these changes is a severe rise in intracranial pressure leading to decreased cerebral perfusion pressure, cessation of cerebral blood flow and ultimately global ischaemia and oedema ${ }^{98-100}$. The intracranial hypertension at ictus is often greater than systolic blood pressure, and the rate of increase and peak intracranial pressure appears to be proportional to the amount of arterial blood extravasating into the subarachnoid spaces from the aneurysm ${ }^{101-103}$. Cerebral spinal fluid outflow obstruction, in addition to hydrocephalus, further exacerbates intracranial hypertension ${ }^{104,105}$. However, the increase in intracranial pressure is not uniform and there are two distinct groups of patients in terms of their intracranial hypertension. The first, more common, scenario is an increase in intracranial pressure to the arterial diastolic pressure which then decreases to just above the patient's baseline intracranial pressure ${ }^{102}$. These patients typically have a small volume haemorrhage with cerebral oedema. The second type of increased intracranial pressure is sustained due to either a progressive haematoma or acute hydrocephalus ${ }^{104,105}$.

The cerebral oedema seen after aSAH is often present on admission CT scans and becomes more common, being present in up to $20 \%$ of patients by day $6^{98}$. Cerebral oedema is itself a poor prognostic factor after aSAH ${ }^{98,106,107}$. The global cerebral ischaemia that occurs during the initial aSAH may lead to the disruption of the bloodbrain barrier, and initiate cell death mechanisms and inflammatory responses which all contribute to cerebral oedema. Regulated and 
unregulated neuronal cell death appears to occur within 24 hours after aSAH and as early as 40 minutes after the initial injury ${ }^{108-110}$. Serum and cerebrospinal fluid (CSF) levels of pro-inflammatory cytokines and vasoactive factors, such as tumour necrosis factor- $\alpha$, interleukin-6, and interleukin-1 receptor antagonist, correlate with DCI and poor outcomes ${ }^{111,112}$.

In addition to these inflammatory responses, blood degradation products are thought to contribute to DCI and perhaps removing blood from the subarachnoid space may improve outcomes ${ }^{30,113}$. Continuous cisternal drainage and intrathecal administration of thrombolytics have been trailed with reports of success, and results of the EARLYDRAIN trial comparing continuous lumbar-CSF drainage with standard treatment are awaited ${ }^{114,115}$. A meta-analysis of the use of intrathecal thrombolytics suggested a reduction in the incidence of DCI but these findings were not statistically significant after excluding one study, which included intrathecal nimodipine in addition to thrombolytic therapy ${ }^{116}$.

Cerebral autoregulation, the ability of blood vessels to maintain constant cerebral blood flow $(\mathrm{CBF})$ with arterial blood pressures between $\sim 60$ and $150 \mathrm{mmHg}$, is impaired after the aneurysm rupture $^{117-119}$. Once impaired, autoregulation starts to rely on cerebral perfusion pressure and blood viscosity. Because of this, any change in intracranial pressure or systemic arterial pressure can potentially worsen oedema and ischaemia.

A limitation to many of these theories is that the majority of data comes from animal studies of experimental aSAH models. Some authors have questioned whether we can reliably translate data derived from this model to human studies ${ }^{120,121}$. We await the results of a systematic review and meta-analysis of intracranial in vivo animal studies of EBI and delayed cerebral arterial vessel narrowing after aSAH ${ }^{122}$. The review aims to analyse aSAH models and define standard experimental parameters and endpoints for the study of EBI after aSAH and aSAH models of delayed cerebral arterial vessel narrowing.

\section{Cortical spreading depolarisation}

Cortical spreading depolarisation (CSD), also termed cortical spreading depression, reflects a wave of depolarisation that spreads across grey matter at $2-5 \mathrm{~mm} / \mathrm{min}$. CSD is not a new theory, nor is it limited to aSAH, and has been implicated in brain injuries and migraine $^{123}$. It occurs when a cation influx across cellular membranes exceeds the $\mathrm{Na}^{+}$and $\mathrm{Ca}^{2+}$ pump action and is followed by water and shrinkage of the extracellular space by $\sim 70 \%$ causing depression of EEG (electroencephalography) activity ${ }^{124,125}$. Because the $\mathrm{Na}^{+}$and $\mathrm{Ca}^{2+}$ pump is ATP-dependent, to counteract the passive influx of cations across the membrane energy consumption increases, which leads to increased regional blood flow requirements. When there is a dysfunction of the vasculature in the region, as occurs after aSAH, severe microvascular spasm can occur, rather than vasodilation, causing "cortical spreading ischaemia" 125 . There is evidence that CSD occurs after the initial aneurysm rupture from both animal and human studies, and it is thought that after each depolarisation hypoperfusion of the cortex occurs due to vasoconstriction ${ }^{126}$. Furthermore, up to $75 \%$ of all CSD episodes occur between days
5 and 7 after the aSAH, which matches DCI chronology ${ }^{127}$. Another link between CSD and DCI comes from the CoOperative Study on Brain Injury Depolarisations (COSBID), which demonstrated that repeated CSD preceded DCI with little evidence of "vasospasm" on digital subtraction angiography (DSA), albeit in a small sample (thirteen patients) ${ }^{128}$.

\section{Microthrombosis}

Increased levels of procoagulants have been seen prior to DCI, specifically an increased von Willebrand factor 72 hours after aSAH and increased platelet-activating factors on day $4^{129-132}$. Microthrombi have also been identified at the autopsy of patients after aSAH, suggesting that they are involved in aSAH pathology ${ }^{132}$. The rate of rebleeding following aSAH has been significantly reduced following tranexamic acid administration. However, it may have led to an increased incidence of DCI separate from large vessel narrowing, possibly because the antifibrinolytic therapy caused microthrombosis and promoted DCI ${ }^{133-136}$. Unfortunately, the results of studies investigating antiplatelet agents in the treatment of microthrombosis after aSAH have been largely negative, including those investigating prophylactic low-molecular-weight heparin ${ }^{137,138}$.

\section{Therapies}

Intrathecal therapies

Intrathecal administration of nicardipine, a dihydropyridine calcium channel blocker, has been demonstrated in a number of clinical studies with varying results. Susuki et al. examined a series of 177 patients with Fisher grade III aSAH undergoing aneurysmal clipping and cisternal drainage within 48 hours of the aSAH ${ }^{139}$. Patients received $4 \mathrm{mg}$ intrathecal therapy nicardipine every 12 hours on days 3-14 postoperatively. Of these patients, $11.3 \%$ had radiographic evidence of vessel narrowing and $5.7 \%$ had clinical signs of DCI. The authors note a significant reduction in "vasospasm" but also recognise that $18.6 \%$ of patients required a shunt operation. Shibuya et al. demonstrated a decreased incidence of DCI and angiographic vessel constriction by 20 and $26 \%$ respectively after prophylactic administration of $2 \mathrm{mg}$ intrathecal therapy nicardipine via a cisternal drain when compared with control patients ${ }^{140}$. More recent trials also report positive findings, but are limited to cases of refractory "vasospasm" and have very small sample sizes ${ }^{141,142}$. However, nicardipine is associated with probable vasodilationassociated headaches, intracranial infections and hydrocephalus, and positive long-term outcomes from large RCTs are lacking. The NEWTON trial is a phase I/IIa multicentre RCT administering intrathecal nimodipine in patients with aSAH ${ }^{143}$. The trial uses EG-1962, a sustained delivery system of nimodipine in microparticles. These will be injected into the ventricles through an external ventricular catheter in patients undergoing coiling or clipping of ruptured aneurysms. It is thought that systemic effects are less likely to occur as nimodipine concentrations are much lower in the plasma than $\mathrm{CSF}^{144}$. We await the results of this trial and subsequent progressive trials with interest.

\section{Pleiotropic interventions}

Statins have been investigated as a potential treatment for DCI due to their multiple effects, although a recent meta-analysis of the four single-centre RCTs demonstrated no benefit from statins after 
$\operatorname{aSAH}^{145}$. Despite evidence that statins can reduce the duration of impaired autoregulation after aSAH, two more recent multicentre RCTs found no benefit from statin administration after aSAH ${ }^{146-148}$.

Another potential agent in the treatment of DCI is cilostazol, a phosphodiesterase 3 inhibitor and platelet aggregation inhibitor that affects smooth muscle cells. A meta-analysis of two RCTs and two quasi-RCTs demonstrated amelioration of cerebral vessel narrowing and a benefit on outcome at discharge, even after excluding the lower quality studies ${ }^{149-151}$. A subsequent trial has echoed these findings, but only one study has reported long-term outcomes and did not demonstrate improved outcomes with cilostazol ${ }^{151,152}$.

\section{Conclusion}

In summary, cerebral vessel narrowing is consistently seen after aSAH, but its location and severity is not predictably linked to DCI. There is no conclusive evidence to support the treatment of vessel narrowing in the management of DCI, despite some studies reporting improved outcomes, specifically after more invasive techniques. Nimodipine is the only effective treatment for DCI but we still do not understand how nimodopine exerts its neuroprotective effect, although it does not seem to work by reversing cerebral artery narrowing, at least not in large vessels. It is possible that we are not detecting microvascular vasoconstriction or ischaemia on CT and TCD and so our understanding of the pathology is limited. Furthermore, improved recognition of DCI clinically, from imaging and/or biochemical markers would not only allow for quicker treatment but also better assessment of interventions. DCI almost certainly has a multifactorial aetiology and it may be that only by combining interventions will we see improved outcomes, but first we must understand the aetiology. Understanding how nimodipine, the only drug with proven efficacy, exerts its effect may be the key to creating new interventions with improved efficacy. There remains a large amount of work to be done in understanding DCI and investigating future potential treatments.

\section{Author contributions}

Both authors were involved in the writing and revision of the manuscript and have agreed to the final content.

\section{Competing interests}

The authors declare that they have no competing interests.

\section{Grant information}

The author(s) declared that no grants were involved in supporting this work.
1. Linn FH, Rinkel GJ, Algra A, et al.: Incidence of subarachnoid hemorrhage: role of region, year, and rate of computed tomography: a meta-analysis. Stroke. 1996; 27(4): 625-9.

PubMed Abstract | Publisher Full Tex

2. Epidemiology of aneurysmal subarachnoid hemorrhage in Australia and New Zealand: incidence and case fatality from the Australasian Cooperative Research on Subarachnoid Hemorrhage Study (ACROSS). Stroke. 2000; 31(8): 1843-50.

PubMed Abstract | Publisher Full Text

3. Zacharia BE, Hickman ZL, Grobelny BT, et al.: Epidemiology of aneurysmal subarachnoid hemorrhage. Neurosurg Clin N Am. 2010; 21(2): 221-33. PubMed Abstract | Publisher Full Text

4. de Rooij NK, Linn FH, van der Plas JA, et al.: Incidence of subarachnoid haemorrhage: a systematic review with emphasis on region, age gender and time trends. J Neurol Neurosurg Psychiatry. 2007; 78(12): 1365-72. PubMed Abstract | Publisher Full Text | Free Full Text

5. Hop JW, Rinkel GJ, Algra A, et al.: Case-fatality rates and functional outcome after subarachnoid hemorrhage: a systematic review. Stroke. 1997; 28(3): $660-4$.

PubMed Abstract | Publisher Full Text

6. Venti M: Subarachnoid and intraventricular hemorrhage. Front Neurol Neurosci. 2012; 30: 149-53.

PubMed Abstract | Publisher Full Text

7. Rivero-Arias O, Gray A, Wolstenholme J: Burden of disease and costs of aneurysmal subarachnoid haemorrhage (aSAH) in the United Kingdom. Cost Eff Resour Alloc. 2010; 8: 6.

PubMed Abstract | Publisher Full Text | Free Full Text

8. Rabinstein AA, Friedman JA, Weigand SD, et al:: Predictors of cerebral infarction in aneurysmal subarachnoid hemorrhage. Stroke. 2004; 35(8): 1862-6. PubMed Abstract | Publisher Full Text

9. Kassell NF, Torner JC, Haley EC Jr, et al:: The International Cooperative Study on the Timing of Aneurysm Surgery. Part1: Overall management results. J Neurosurg. 1990; 73(1): 18-36.

PubMed Abstract | Publisher Full Text

10. Brilstra EH, Rinkel GJ, Algra A, et al:: Rebleeding, secondary ischemia, and timing of operation in patients with subarachnoid hemorrhage. Neurology. 2000; 55(11): 1656-60.

PubMed Abstract | Publisher Full Text

11. Hijdra A, van Gijn J, Stefanko S, et al.: Delayed cerebral ischemia after aneurysmal subarachnoid hemorrhage: clinicoanatomic correlations. Neurology. 1986; 36(3): 329-33.

PublMed Abstract | Publisher Full Text

12. F Al-Tamimi YZ, Orsi NM, Quinn AC, et al:: A review of delayed ischemic neurologic deficit following aneurysmal subarachnoid hemorrhage: historical overview, current treatment, and pathophysiology. World Neurosurg. 2010; 73(6): 654-67.

PubMed Abstract | Publisher Full Text | F1000 Recommendation

13. F Rowland MJ, Hadjipavlou G, Kelly M, et al.: Delayed cerebral ischaemia after subarachnoid haemorrhage: looking beyond vasospasm. Br J Anaesth. 2012; 109(3): 315-29.

PubMed Abstract | Publisher Full Text | F1000 Recommendation

14. F Budohoski KP, Guilfoyle M, Helmy A, et al.: The pathophysiology and treatment of delayed cerebral ischaemia following subarachnoid haemorrhage. J Neurol Neurosurg Psychiatry. 2014; 85(12): 1343-53. PubMed Abstract | Publisher Full Text | F1000 Recommendation

15. F Cossu G, Messerer M, Oddo M, et al:: To look beyond vasospasm in aneurysmal subarachnoid haemorrhage. Biomed Res Int. 2014; 2014: 628597. PubMed Abstract | Publisher Full Text | Free Full Text | F1000 Recommendation

16. Vergouwen MD, Vermeulen $\mathrm{M}$, van Gijn J, et al: Definition of delayed cerebra ischemia after aneurysmal subarachnoid hemorrhage as an outcome event in clinical trials and observational studies: proposal of a multidisciplinary research group. Stroke. 2010; 41(10): 2391-5. PubMed Abstract | Publisher Full Text

17. F Diringer MN, Bleck TP, Claude Hemphill J 3rd, et al:: Critical care management of patients following aneurysmal subarachnoid hemorrhage: recommendations from the Neurocritical Care Society's Multidisciplinary Consensus Conference. Neurocrit Care. 2011; 15(2): 211-40. PubMed Abstract | Publisher Full Text | F1000 Recommendation

18. Ecker A, Riemenschneider PA: Arteriographic demonstration of spasm of the 
intracranial arteries, with special reference to saccular arterial aneurysms. $J$ Neurosurg. 1951; 8(6): 660-7.

PubMed Abstract | Publisher Full Text

19. Allcock JM, Drake CG: Postoperative angiography in cases of ruptured intracranial aneurysm. J Neurosurg. 1963; 20: 752-9. PubMed Abstract

20. Weir B, Grace M, Hansen J, et al:: Time course of vasospasm in man. J Neurosurg. 1978; 48(2): 173-8. PubMed Abstract | Publisher Full Tex

21. Fisher CM, Kistler JP, Davis JM: Relation of cerebral vasospasm to subarachnoid hemorrhage visualized by computerized tomographic scanning. Neurosurgery. 1980; 6(1): 1-9.

PubMed Abstract | Publisher Full Text

22. Wilkins RH: Cerebral vasospasm. Crit Rev Neurobiol. 1990; 6(1): 51-77. PubMed Abstract

23. Dorsch NW, King MT: A review of cerebral vasospasm in aneurysmal subarachnoid haemorrhage Part I: Incidence and effects. J Clin Neurosci. 1994 1(1): 19-26.

PubMed Abstract | Publisher Full Text

24. Harders AG, Gilsbach JM: Time course of blood velocity changes related to vasospasm in the circle of Willis measured by transcranial Dopple ultrasound. J Neurosurg. 1987; 66(5): 718-28.

PubMed Abstract | Publisher Full Text

25. Reilly C, Amidei C, Tolentino J, et al:: Clot volume and clearance rate as independent predictors of vasospasm after aneurysmal subarachnoid hemorrhage. J Neurosurg. 2004; 101(2): 255-61. PubMed Abstract | Publisher Full Text

26. Dankbaar JW, Rijsdijk M, van der Schaaf IC, et al: Relationship between vasospasm, cerebral perfusion, and delayed cerebral ischemia after aneurysmal subarachnoid hemorrhage. Neuroradiology. 2009; 51(12): 813-9. PubMed Abstract | Publisher Full Text | Free Full Text

27. Toda N, Shimizu K, Ohta T: Mechanism of cerebral arterial contraction induced by blood constituents. J Neurosurg. 1980; 53(3): 312-22. PubMed Abstract

28. Toda N: Mechanisms of contracting action of oxyhemoglobin in isolated monkey and dog cerebral arteries. Am J Physiol. 1990; 258(1 Pt 2): H57-63. PubMed Abstract

29. Macdonald RL, Weir BK, Grace MG, et al:: Morphometric analysis of monkey cerebral arteries exposed in vivo to whole blood, oxyhemoglobin, methemoglobin, and bilirubin. Blood Vessels. 1991; 28(6): 498-510. PubMed Abstract

30. Macdonald RL, Weir BK: A review of hemoglobin and the pathogenesis of cerebral vasospasm. Stroke. 1991; 22(8): 971-82.

PubMed Abstract | Publisher Full Tex

31. Goretski J, Hollocher TC: Trapping of nitric oxide produced during denitrification by extracellular hemoglobin. J Biol Chem. 1988; 263(5): 2316-23. PubMed Abstract

32. Ignarro LJ: Biosynthesis and metabolism of endothelium-derived nitric oxide. Annu Rev Pharmacol Toxicol. 1990; 30: 535-60. PubMed Abstract | Publisher Full Text

33. Pluta RM: Delayed cerebral vasospasm and nitric oxide: review, new hypothesis, and proposed treatment. Pharmacol Ther. 2005; 105(1): 23-56. PubMed Abstract | Publisher Full Tex

34. Hino A, Tokuyama $\mathrm{Y}$, Weir $\mathrm{B}$, et al:: Changes in endothelial nitric oxide synthase mRNA during vasospasm after subarachnoid hemorrhage in monkeys. Neurosurgery. 1996; 39(3): 562-7; discussion 567-8. PubMed Abstract | Publisher Full Text

35. Jung CS, Iuliano BA, Harvey-White J, et al.: Association between cerebrospinal fluid levels of asymmetric dimethyl-L-arginine, an endogenous inhibitor of endothelial nitric oxide synthase, and cerebral vasospasm in a primate model of subarachnoid hemorrhage. J Neurosurg. 2004: 101(5): 836-42. PubMed Abstract | Publisher Full Text

36. Thomas JE, Nemirovsky A, Zelman V, et al.: Rapid reversal of endothelin-1induced cerebral vasoconstriction by intrathecal administration of nitric oxide donors. Neurosurgery. 1997; 40(6): 1245-9.

PubMed Abstract | Publisher Full Tex

37. Pluta RM, Oldfield EH, Boock RJ: Reversal and prevention of cerebral vasospasm by intracarotid infusions of nitric oxide donors in a primate mode of subarachnoid hemorrhage. J Neurosurg. 1997; 87(5): 746-51. PubMed Abstract | Publisher Full Tex

38. Raabe A, Zimmermann M, Setzer M, et al.: Effect of intraventricular sodium nitroprusside on cerebral hemodynamics and oxygenation in poor-grade aneurysm patients with severe, medically refractory vasospasm. Neurosurgery. 2002; 50(5): 1006-13; discussion 1013-4. PubMed Abstract | Publisher Full Tex

39. F Kida K, Ichinose F: Preventing ischemic brain injury after sudden cardiac arrest using NO inhalation. Crit Care. 2014; 18(2): 212. PubMed Abstract | Publisher Full Text | Free Full Text | F1000 Recommendation

40. F Garry PS, Ezra M, Rowland MJ, et al.: The role of the nitric oxide pathway in brain injury and its treatment--from bench to bedside. Exp Neurol. 2015; 263: $235-43$.

PubMed Abstract | Publisher Full Text | F1000 Recommendation
41. F Thampatty BP, Sherwood PR, Gallek MJ, et al.: Role of endothelin-1 in uman aneurysmal subarachnoid hemorrhage: associations with vasospasm and delayed cerebral ischemia. Neurocrit Care. 2011; 15(1): 19-27. PubMed Abstract | Publisher Full Text | Free Full Text | F1000 Recommendation

42. Pluta RM, Boock RJ, Afshar JK, et al.: Source and cause of endothelin-1 release into cerebrospinal fluid after subarachnoid hemorrhage. J Neurosurg. 1997; 87(2): 287-93.

PubMed Abstract | Publisher Full Text

43. Juvela S: Plasma endothelin concentrations after aneurysmal subarachnoid hemorrhage. J Neurosurg 2000; 92(3): 390-400.

PubMed Abstract | Publisher Full Tex

44. Seifert V, Löffler BM, Zimmermann M, et al.: Endothelin concentrations in patients with aneurysmal subarachnoid hemorrhage. Correlation with cerebral vasospasm, delayed ischemic neurological deficits, and volume of hematoma. J Neurosurg. 1995; 82(1): 55-62. PublMed Abstract | Publisher Full Text

45. Mascia L, Fedorko L, Stewart DJ, et al.: Temporal relationship between endothelin-1 concentrations and cerebral vasospasm in patients with aneurysmal subarachnoid hemorrhage. Stroke. 2001; 32(5): 1185-90. PubMed Abstract | Publisher Full Text

46. Kokkoris $\mathrm{S}$, Andrews $\mathrm{P}$, Webb DJ: Role of calcitonin gene-related peptide in cerebral vasospasm, and as a therapeutic approach to subarachnoid hemorrhage. Front Endocrinol (Lausanne). 2012; 3: 135. PubMed Abstract | Publisher Full Text | Free Full Text

47. Arienta C, Balbi S, Caroli M, et al:: Depletion of calcitonin gene-related peptide in perivascular nerves during acute phase of posthemorrhagic vasospasm in the rabbit. Brain Res Bull. 1991; 27(5): 605-9.

PubMed Abstract | Publisher Full Text

48. Juul $\mathrm{R}$, Hara $\mathrm{H}$, Gisvold $\mathrm{SE}$, et al.: Alterations in perivascular dilatory neuropeptides (CGRP, SP, VIP) in the external jugular vein and in the cerebrospinal fluid following subarachnoid haemorrhage in man. Acta Neurochir (Wien). 1995; 132(1-3): 32-41.

PubMed Abstract | Publisher Full Tex

49. Nozaki K, Kikuchi H, Mizuno N: Changes of calcitonin gene-related peptidelike immunoreactivity in cerebrovascular nerve fibers in the dog after experimentally produced subarachnoid hemorrhage. Neurosci Lett. 1989; 102(1): 27-32.

PubMed Abstract | Publisher Full Text

50. Effect of calcitonin-gene-related peptide in patients with delayed postoperative cerebral ischaemia after aneurysmal subarachnoid haemorrhage. European CGRP in Subarachnoid Haemorrhage Study Group. Lancet. 1992; 339(8797): 831-4 PubMed Abstract | Publisher Full Text

51. Vora YY, Suarez-Almazor M, Steinke DE, et al:: Role of transcranial Doppler monitoring in the diagnosis of cerebral vasospasm after subarachnoid hemorrhage. Neurosurgery. 1999; 44(6): 1237-47; discussion 1247-8. PubMed Abstract

52. Dehdashti AR, Mermillod B, Rufenacht DA, et al.: Does treatment modality of intracranial ruptured aneurysms influence the incidence of cerebral vasospasm and clinical outcome? Cerebrovasc Dis. 2004; 17(1): 53-60. PubMed Abstract | Publisher Full Text

53. Ohta $\mathrm{H}$, Ito $\mathrm{Z}$ : [Cerebral infarction due to vasospasm, revealed by computed tomography (author's transI)]. Neurol Med Chir (Tokyo). 1981; 21(4): 365-72. PubMed Abstract | Publisher Full Text

54. Dorsch NW: Cerebral arterial spasm--a clinical review. Br J Neurosurg. 1995 9(3): 403-12. PubMed Abstract | Publisher Full Text

55. Hijdra A, van Gijn J, Nagelkerke NJ, et al:: Prediction of delayed cerebral ischemia, rebleeding, and outcome after aneurysmal subarachnoid hemorrhage. Stroke. 1988; 19(10): 1250-6. PubMed Abstract | Publisher Full Text

56. F Rodríguez García PL, Rodríguez Pupo LR, Rodríguez García D: [Diagnosis of delayed cerebral ischaemia and cerebral vasospasm in subarachnoid haemorrhage]. Neurologia. 2010; 25(5): 322-30. PubMed Abstract | Publisher Full Text | F1000 Recommendation

57. Hirashima $Y$, Kurimoto $M$, Takaba $M$, et al:: The use of computed tomography in the prediction of delayed cerebral infarction following acute aneurysm surgery for subarachnoid haemorrhage. Acta Neurochir (Wien). 1995; 132(1-3): 9-13. PubMed Abstract | Publisher Full Text

58. Forssell A, Larsson C, Rönnberg J, et al.: CT assessment of subarachnoid haemorrhage. A comparison between different CT methods of grading subarachnoid haemorrhage. Br J Neurosurg. 1995; 9(1): 21-7. PubMed Abstract | Publisher Full Text

59. Kivisaari RP, Salonen O, Servo A, et al:: MR imaging after aneurysmal subarachnoid hemorrhage and surgery: a long-term follow-up study. AJNR Am J Neuroradiol. 2001; 22(6): 1143-8. PubMed Abstract

60. Weidauer S, Lanfermann H, Raabe A, et al:: Impairment of cerebral perfusion and infarct patterns attributable to vasospasm after aneurysmal subarachnoid hemorrhage: a prospective MRI and DSA study. Stroke. 2007; 38(6): 1831-6. PubMed Abstract | Publisher Full Tex

61. Rabinstein AA, Weigand S, Atkinson JL, et al.: Patterns of cerebral infarction in 
aneurysmal subarachnoid hemorrhage. Stroke. 2005; 36(5): 992-7. PubMed Abstract | Publisher Full Text

62. F Brown RJ, Kumar A, Dhar R, et al:: The relationship between delayed infarcts and angiographic vasospasm after aneurysmal subarachnoid hemorrhage. Neurosurgery. 2013; 72(5): 702-7; discussion 707-8. PubMed Abstract | Publisher Full Text | Free Full Text | F1000 Recommendation

63. F Crowley RW, Medel R, Dumont AS, et al:: Angiographic vasospasm is strongly correlated with cerebral infarction after subarachnoid hemorrhage. Stroke. 2011; 42(4): 919-23.

PubMed Abstract | Publisher Full Text | F1000 Recommendation

64. Herz DA, Baez S, Shulman K: Pial microcirculation in subarachnoid hemorrhage. Stroke. 1975; 6(4): 417-24. PubMed Abstract | Publisher Full Text

65. Ohkuma H, Itoh K, Shibata S, et al.: Morphological changes of intraparenchyma arterioles after experimental subarachnoid hemorrhage in dogs. Neurosurgery. 1997; 41(1): 230-5; discussion 235-6.

PubMed Abstract | Publisher Full Tex

66. Ohkuma H, Manabe H, Tanaka M, et al:: Impact of cerebral microcirculatory changes on cerebral blood flow during cerebral vasospasm after aneurysmal subarachnoid hemorrhage. Stroke. 2000; 31(7): 1621-7. PubMed Abstract | Publisher Full Text

67. F Friedrich B, Müller F, Feiler S, et al.: Experimental subarachnoid hemorrhage causes early and long-lasting microarterial constriction and microthrombosis: an in-vivo microscopy study. J Cereb Blood Flow Metab. 2012; 32(3): 447-55. PubMed Abstract | Publisher Full Text | Free Full Text | F1000 Recommendation

68. Uhl E, Lehmberg J, Steiger HJ, et al.: Intraoperative detection of early microvasospasm in patients with subarachnoid hemorrhage by using orthogonal polarization spectral imaging. Neurosurgery. 2003; 52(6): 1307-15; discussion 1315-7.

PubMed Abstract | Publisher Full Text

69. Pennings FA, Bouma GJ, Ince C: Direct observation of the human cerebral microcirculation during aneurysm surgery reveals increased arteriolar contractility. Stroke. 2004; 35(6): 1284-8.

PubMed Abstract | Publisher Full Text

70. F Dankbaar JW, de Rooij NK, Velthuis BK, et al:: Diagnosing delayed cerebral ischemia with different CT modalities in patients with subarachnoid hemorrhage with clinical deterioration. Stroke. 2009; 40(11): 3493-8. PubMed Abstract | Publisher Full Text | F1000 Recommendation

71. F Sanelli PC, Anumula N, Johnson CE, et al.: Evaluating CT perfusion using outcome measures of delayed cerebral ischemia in aneurysmal subarachnoid hemorrhage. AJNR Am J Neuroradiol. 2013; 34(2): 292-8. PubMed Abstract | Publisher Full Text | Free Full Text | F1000 Recommendation

72. F Dankbaar JW, de Rooij NK, Smit EJ, et al:: Changes in cerebral perfusion around the time of delayed cerebral ischemia in subarachnoid hemorrhage patients. Cerebrovasc Dis. 2011; 32(2): 133-40. PubMed Abstract | Publisher Full Text | F1000 Recommendation

73. F Killeen RP, Mushlin Al, Johnson CE, et al:: Comparison of CT perfusion and digital subtraction angiography in the evaluation of delayed cerebral ischemia. Acad Radiol. 2011; 18(9): 1094-100.

PubMed Abstract | Publisher Full Text | Free Full Text | F1000 Recommendation

74. F Etminan N, Vergouwen MD, llodigwe D, et al.: Effect of pharmaceutical treatment on vasospasm, delayed cerebral ischemia, and clinical outcome in patients with aneurysmal subarachnoid hemorrhage: a systematic review and meta-analysis. J Cereb Blood Flow Metab. 2011; 31(6): 1443-51. PubMed Abstract | Publisher Full Text | Free Full Text | F1000 Recommendation

75. F Macdonald RL, Higashida RT, Keller E, et al:: Clazosentan, an endothelin receptor antagonist, in patients with aneurysmal subarachnoid haemorrhage undergoing surgical clipping: a randomised, double-blind, placebo-controlled phase 3 trial (CONSCIOUS-2). Lancet Neurol. 2011; 10(7): 618-25. PubMed Abstract | Publisher Full Text | F1000 Recommendation

76. F Macdonald RL, Kassell NF, Mayer S, et al.: Clazosentan to overcome neurological ischemia and infarction occurring after subarachnoid hemorrhage (CONSCIOUS-1): randomized, double-blind, placebo-controlled phase 2 dose-finding trial. Stroke. 2008; 39(11): 3015-21. PubMed Abstract | Publisher Full Text | F1000 Recommendation

77. F Laban KG, Vergouwen MD, Dijkhuizen RM, et al:: Effect of endothelin receptor antagonists on clinically relevant outcomes after experimenta subarachnoid hemorrhage: a systematic review and meta-analysis. J Cereb Blood Flow Metab. 2015; 35(7): 1085-9. PubMed Abstract | Publisher Full Text | F1000 Recommendation

78. F Kimball MM, Velat GJ, Hoh BL, et al.: Critical care guidelines on the endovascular management of cerebral vasospasm. Neurocrit Care. 2011; 15(2) 336-41.

PubMed Abstract | Publisher Full Text | F1000 Recommendation

79. Atkins $D$, Best D, Briss PA, et al:: Grading quality of evidence and strength of recommendations. BMJ. 2004; 328(7454): 1490. PubMed Abstract | Publisher Full Text | Free Full Text

80. Kazda S, Towart R: Nimodipine: a new calcium antagonistic drug with a preferential cerebrovascular action. Acta Neurochir (Wien). 1982; 63(1-4): $259-65$.

PubMed Abstract | Publisher Full Text
81. Ljunggren $\mathrm{B}$, Brandt $\mathrm{L}$, Säveland $\mathrm{H}$, et al.: Outcome in 60 consecutive patients treated with early aneurysm operation and intravenous nimodipine. J Neurosurg 1984; 61(5): 864-73.

PubMed Abstract | Publisher Full Text

82. Pickard JD, Murray GD, Illingworth R, et al.: Effect of oral nimodipine on cerebral infarction and outcome after subarachnoid haemorrhage: British aneurysm nimodipine trial. BMJ. 1989; 298(6674): 636-42

PubMed Abstract | Free Full Text

83. Dorhout Mees SM, Rinkel GJ, Feigin VL, et al.: Calcium antagonists for aneurysmal subarachnoid haemorrhage. Cochrane Database Syst Rev. 2007; (3): CD000277.

PubMed Abstract | Publisher Full Text

84. van den Bergh WM, Algra A, van der Sprenkel JW, et al:: Hypomagnesemia after aneurysmal subarachnoid hemorrhage. Neurosurgery. 2003; 52(2): 276-81; discussion $281-2$

PubMed Abstract | Publisher Full Text

85. van den Bergh WM, Zuur JK, Kamerling NA, et al:: Role of magnesium in the reduction of ischemic depolarization and lesion volume after experimental subarachnoid hemorrhage. J Neurosurg. 2002; 97(2): 416-22. PublMed Abstract | Publisher Full Text

86. F Dorhout Mees SM, Algra A, Vandertop WP, et al: Magnesium for aneurysmal subarachnoid haemorrhage (MASH-2): a randomised placebo-controlled trial. Lancet. 2012; 380(9836): 44-9.

PubMed Abstract | Publisher Full Text | Free Full Text | F1000 Recommendation

7. Reddy D, Fallah A, Petropoulos JA, et al.: Prophylactic magnesium sulfate for aneurysmal subarachnoid hemorrhage: a systematic review and metaanalysis. Neurocrit Care. 2014; 21(2): 356-64

PubMed Abstract | Publisher Full Text

88. F Wong GK, Poon WS, Chan MT, et al:: Intravenous magnesium sulphate for aneurysmal subarachnoid hemorrhage (IMASH): a randomized, doubleblinded, placebo-controlled, multicenter phase III trial. Stroke. 2010; 41(5): 921-6.

PubMed Abstract | Publisher Full Text | F1000 Recommendation

89. Wong GK, Poon WS, Chan MT, et al:: Plasma magnesium concentrations and clinical outcomes in aneurysmal subarachnoid hemorrhage patients: post hoc analysis of intravenous magnesium sulphate for aneurysmal subarachnoid hemorrhage trial. Stroke. 2010; 41(8): 1841-4 PubMed Abstract | Publisher Full Text

90. Petruk KC, West M, Mohr G, et al:: Nimodipine treatment in poor-grade aneurysm patients. Results of a multicenter double-blind placebo-controlled trial. J Neurosurg. 1988; 68(4): 505-17. PubMed Abstract | Publisher Full Text

91. Feigin VL, Rinkel GJ, Algra A, et al.: Calcium antagonists in patients with aneurysmal subarachnoid hemorrhage: a systematic review. Neurology. 1998; 50(4): 876-83.

PubMed Abstract | Publisher Full Text

92. Pisani A, Calabresi P, Tozzi A, et al.: L-type $\mathrm{Ca}^{2+}$ channel blockers attenuate electrical changes and $\mathrm{Ca}^{2+}$ rise induced by oxygen/glucose deprivation in cortical neurons. Stroke. 1998; 29(1): 196-201; discussion 202. PubMed Abstract | Publisher Full Text

93. Horn J, Limburg M: Calcium antagonists for ischemic stroke: a systematic review. Stroke. 2001; 32(2): 570-6. PubMed Abstract | Publisher Full Text

94. Langham J, Goldfrad C, Teasdale G, et al:: Calcium channel blockers for acute traumatic brain injury. Cochrane Database Syst Rev. 2003; (4): CD000565. PubMed Abstract | Publisher Full Text

95. Vergouwen MD, Vermeulen M, Roos YB: Effect of nimodipine on outcome in patients with traumatic subarachnoid haemorrhage: a systematic review. Lancet Neurol. 2006; 5(12): 1029-32.

PubMed Abstract | Publisher Full Text

96. Vergouwen MD, Vermeulen M, de Haan RJ, et al:: Dihydropyridine calcium antagonists increase fibrinolytic activity: a systematic review. J Cereb Blood Flow Metab. 2007; 27(7): 1293-308.

PubMed Abstract | Publisher Full Text

97. Dreier JP, Windmüller O, Petzold G, et al.: Ischemia triggered by red blood cell products in the subarachnoid space is inhibited by nimodipine administration or moderate volume expansion/hemodilution in rats. Neurosurgery. 2002; 51(6): 1457-65; discussion 1465-7.

PubMed Abstract | Publisher Full Text

98. Claassen J, Carhuapoma JR, Kreiter KT, et al.: Global cerebral edema after subarachnoid hemorrhage: frequency, predictors, and impact on outcome. Stroke. 2002; 33(5): 1225-32.

PubMed Abstract | Publisher Full Text

99. Hop JW, Rinkel GJ, Algra A, et al.: Initial loss of consciousness and risk of delayed cerebral ischemia after aneurysmal subarachnoid hemorrhage. Stroke. 1999; 30(11): 2268-71.

PubMed Abstract | Publisher Full Text

100. Cahill J, Calvert JW, Zhang JH: Mechanisms of early brain injury after subarachnoid hemorrhage. J Cereb Blood Flow Metab. 2006; 26(11): 1341-53. PubMed Abstract | Publisher Full Text

101. Bederson JB, Levy AL, Ding WH, et al:: Acute vasoconstriction after subarachnoid hemorrhage. Neurosurgery. 1998; 42(2): 352-60; discussion 360-2. PubMled Abstract | Publisher Full Text 
102. Bederson JB, Germano IM, Guarino L: Cortical blood flow and cerebral perfusion pressure in a new noncraniotomy model of subarachnoid hemorrhage in the rat. Stroke. 1995; 26(6): 1086-91; discussion 1091-2. PubMed Abstract | Publisher Full Text

103. Schwartz AY, Masago A, Sehba FA, et al:: Experimental models of subarachnoid hemorrhage in the rat: a refinement of the endovascular filament model. $J$ Neurosci Methods. 2000; 96(2): 161-7 PubMed Abstract | Publisher Full Text

104. Nornes $\mathrm{H}$, Magnaes $\mathrm{B}$ : Intracranial pressure in patients with ruptured saccular aneurysm. J Neurosurg. 1972; 36(5): 537-47. PubMed Abstract | Publisher Full Text

105. Asano T, Sano K: Pathogenetic role of no-reflow phenomenon in experimental subarachnoid hemorrhage in dogs. J Neurosurg. 1977; 46(4): 454-66. PubMed Abstract | Publisher Full Text

106. Helbok R, Ko S, Schmidt JM, et al.: Global cerebral edema and brain metabolism after subarachnoid hemorrhage. Stroke. 2011; 42(6): 1534-9. PubMed Abstract | Publisher Full Text

107. Zetterling M, Hallberg L, Ronne-Engström E: Early global brain oedema in relation to clinical admission parameters and outcome in patients with aneurysmal subarachnoid haemorrhage. Acta Neurochir (Wien). 2010; 152(9): 1527-33; discussion 1533 PubMed Abstract | Publisher Full Text

108. Cahill J, Calvert JW, Solaroglu I, et al.: Vasospasm and p53-induced apoptosis in an experimental model of subarachnoid hemorrhage. Stroke. 2006; 37(7): 1868-74.

PubMed Abstract | Publisher Full Text

109. Prunell GF, Svendgaard NA, Alkass K, et al.: Delayed cell death related to acute cerebral blood flow changes following subarachnoid hemorrhage in the rat brain. J Neurosurg. 2005; 102(6): 1046-54. PubMed Abstract | Publisher Full Text

110. Gules I, Satoh M, Nanda A, et al:: Apoptosis, blood-brain barrier, and subarachnoid hemorrhage. Acta Neurochir Suppl. 2003; 86: 483-7. PubMed Abstract | Publisher Full Text

111. Osuka K, Suzuki $Y$, Tanazawa T, et al:: Interleukin-6 and development of vasospasm after subarachnoid haemorrhage. Acta Neurochir (Wien). 1998; 140(9): 943-51.

PubMed Abstract | Publisher Full Text

112. Mathiesen $\mathrm{T}$, Edner $\mathrm{G}$, Ulfarsson $\mathrm{E}$, et al:: Cerebrospinal fluid interleukin-1 receptor antagonist and tumor necrosis factor-alpha following subarachnoid hemorrhage. J Neurosurg. 1997; 87(2): 215-20. PubMed Abstract | Publisher Full Text

113. Buckell $\mathrm{M}$ : demonstration of substances capable of contracting smooth muscle in the haematoma fluid from certain cases of ruptured cerebral aneurysm. J Neurol Neurosurg Psychiatry. 1964; 27: 198-9. PubMed Abstract | Publisher Full Text | Free Full Text

114. Sonobe M, Takahashi S, Otsuki T, et al.: [Preventive effect on intracranial arterial vasospasm using combined ventriculo-cisternal and cisternal drainage (author's transI)]. No Shinkei Geka. 1981; 9(12): 1393-7. PubMed Abstract

115. Bardutzky J, Witsch J, Jüttler E, et al: EARLYDRAIN- outcome after early lumbar CSF-drainage in aneurysmal subarachnoid hemorrhage: study protocol for a randomized controlled trial. Trials. 2011; 12: 203 PubMed Abstract | Publisher Full Text | Free Full Text

116. F Kramer AH, Fletcher JJ: Locally-administered intrathecal thrombolytics following aneurysmal subarachnoid hemorrhage: a systematic review and meta-analysis. Neurocrit Care. 2011; 14(3): 489-99.

PubMed Abstract | Publisher Full Text | F1000 Recommendation

117. Rätsep $\mathrm{T}$, Asser $\mathrm{T}$ : Cerebral hemodynamic impairment after aneurysmal subarachnoid hemorrhage as evaluated using transcranial Doppler ultrasonography: relationship to delayed cerebral ischemia and clinical outcome. J Neurosurg. 2001; 95(3): 393-401. PubMed Abstract | Publisher Full Tex

118. Lang EW, Diehl RR, Mehdorn HM: Cerebral autoregulation testing after aneurysmal subarachnoid hemorrhage: the phase relationship between arterial blood pressure and cerebral blood flow velocity. Crit Care Med. 2001; 29(1): 158-63. PubMed Abstract | Publisher Full Text

119. Paulson OB, Strandgaard S, Edvinsson L: Cerebral autoregulation. Cerebrovasc Brain Metab Rev. 1990; 2(2): 161-92. PubMed Abstract

120. Swift DM, Solomon RA: Subarachnoid hemorrhage fails to produce vasculopathy or chronic blood flow changes in rats. Stroke. 1988; 19(7): 878-82. PubMed Abstract | Publisher Full Text

121. Aoki T, Nishimura M: The development and the use of experimental animal models to study the underlying mechanisms of CA formation. J Biomed Biotechnol. 2011; 2011: 535921. PubMed Abstract | Publisher Full Text | Free Full Text

122. Marbacher S: Systematic review and meta-analysis of intracranial in-vivo animal studies of early brain injury (EBI) and delayed cerebral vasospasm (DCVS) after subarachnoid haemorrhage (SAH). 2015. Reference Source

123. Charles AC, Baca SM: Cortical spreading depression and migraine. Nat Rev
Neurol. 2013; 9(11): 637-44

PubMed Abstract | Publisher Full Text

124. Leao AAP: Spreading depression of activity in the cerebral cortex

J Neurophysiol. 1944; 7: 359-390.

Reference Source

125. Dreier JP, Major S, Manning A, et al.: Cortical spreading ischaemia is a novel process involved in ischaemic damage in patients with aneurysmal subarachnoid haemorrhage. Brain. 2009; 132(Pt 7): 1866-81. PubMed Abstract | Publisher Full Text | Free Full Text

126. Shin HK, Dunn AK, Jones PB, et al.: Vasoconstrictive neurovascular coupling during focal ischemic depolarizations. J Cereb Blood Flow Metab. 2006; 26(8): 1018-30.

PubMled Abstract | Publisher Full Text

127. F Bosche B, Graf R, Ernestus RI, et al:: Recurrent spreading depolarizations after subarachnoid hemorrhage decreases oxygen availability in human cerebral cortex. Ann Neurol. 2010; 67(5): 607-17.

PubMed Abstract | Publisher Full Text | Free Full Text | F1000 Recommendation

128. F Woitzik J, Dreier JP, Hecht N, et al.: Delayed cerebral ischemia and spreading depolarization in absence of angiographic vasospasm after subarachnoid hemorrhage. J Cereb Blood Flow Metab. 2012; 32(2): 203-12. PubMed Abstract | Publisher Full Text | Free Full Text | F1000 Recommendation

129. Yundt KD, Grubb RL Jr, Diringer MN, et al.: Autoregulatory vasodilation of parenchymal vessels is impaired during cerebral vasospasm. J Cereb Blood Flow Metab. 1998; 18(4): 419-24. PubMed Abstract | Publisher Full Text

130. Frijns CJ, Fijnheer R, Algra A, et al: Early circulating levels of endothelial cell activation markers in aneurysmal subarachnoid haemorrhage: associations with cerebral ischaemic events and outcome. J Neurol Neurosurg Psychiatry. 2006; 77(1): 77-83. PubMed Abstract | Publisher Full Text | Free Full Text

131. Ikeda $\mathrm{K}$, Asakura $\mathrm{H}$, Futami $\mathrm{K}$, et al: Coagulative and fibrinolytic activation in cerebrospinal fluid and plasma after subarachnoid hemorrhage. Neurosurgery. 1997; 41(2): 344-9; discussion 349-50 PubMed Abstract | Publisher Full Tex

132. Stein SC, Browne KD, Chen XH, et al: Thromboembolism and delayed cerebra ischemia after subarachnoid hemorrhage: an autopsy study. Neurosurgery. 2006; 59(4): 781-7; discussion 787-8. PubMed Abstract | Publisher Full Text

133. Baharoglu MI, Germans MR, Rinkel GJ, et al:: Antifibrinolytic therapy for aneurysmal subarachnoid haemorrhage. Cochrane Database Syst Rev. 2013; 8 : CD001245

PubMed Abstract | Publisher Full Text

134. Roos YB, Rinkel GJ, Vermeulen M, et al.: Antifibrinolytic therapy for aneurysmal subarachnoid haemorrhage. Cochrane Database Syst Rev. 2003; (2): CD001245. PubMed Abstract | Publisher Full Text

135. Vermeulen M, Lindsay KW, Murray GD, et al.: Antifibrinolytic treatment in subarachnoid hemorrhage. N Engl J Med. 1984; 311(7): 432-7. PubMed Abstract | Publisher Full Text

136. Tsementzis SA, Hitchcock ER, Meyer $\mathrm{CH}$ : Benefits and risks of antifibrinolytic therapy in the management of ruptured intracranial aneurysms. A double-blind placebo-controlled study. Acta Neurochir (Wien). 1990; 102(1-2): 1-10. PubMed Abstract | Publisher Full Text

137. Dorhout Mees SM, van den Bergh WM, Algra A, et al:: Antiplatelet therapy for aneurysmal subarachnoid haemorrhage. Cochrane Database Syst Rev. 2007; (4): CD006184.

PubMed Abstract | Publisher Full Text

138. Siironen J, Juvela S, Varis J, et al:: No effect of enoxaparin on outcome of aneurysmal subarachnoid hemorrhage: a randomized, double-blind, placebocontrolled clinical trial. J Neurosurg. 2003; 99(6): 953-9. PubMed Abstract | Publisher Full Text

139. Suzuki M, Doi M, Otawara $Y$, et al.: Intrathecal administration of nicardipine hydrochloride to prevent vasospasm in patients with subarachnoid hemorrhage. Neurosurg Rev. 2001; 24(4): 180-4. PubMed Abstract | Publisher Full Text

140. Shibuya $\mathrm{M}$, Suzuki $\mathrm{Y}$, Enomoto $\mathrm{H}$, et al.: Effects of prophylactic intratheca administrations of nicardipine on vasospasm in patients with severe aneurysmal subarachnoid haemorrhage. Acta Neurochir (Wien). 1994; 131(1-2): 19-25.

PubMed Abstract | Publisher Full Text

141. Goodson K, Lapointe M, Monroe T, et al.: Intraventricular nicardipine for refractory cerebral vasospasm after subarachnoid hemorrhage. Neurocrit Care. 2008; 8(2): 247-52. PubMed Abstract | Publisher Full Tex

142. Ehtisham A, Taylor S, Bayless L, et al:: Use of intrathecal nicardipine for aneurysmal subarachnoid hemorrhage-induced cerebral vasospasm. South Med J. 2009; 102(2): 150-3. PubMed Abstract | Publisher Full Text

143. Etminan N, Macdonald RL, Davis C, et al.: Intrathecal application of the nimodipine slow-release microparticle system eg-1962 for prevention of delayed cerebral ischemia and improvement of outcome after aneurysmal subarachnoid hemorrhage. Acta Neurochir Suppl. 2015; 120: 281-6. PubMed Abstract

144. Hänggi D, Etminan N, Macdonald RL, et al:: NEWTON: Nimodipine Microparticles 
to Enhance Recovery While Reducing Toxicity After Subarachnoid Hemorrhage. Neurocrit Care. 2015; 23(2): 274-84. PubMed Abstract | Publisher Full Text

145. F Vergouwen MD, de Haan RJ, Vermeulen M, et al.: Effect of statin treatment on vasospasm, delayed cerebral ischemia, and functional outcome in patients with aneurysmal subarachnoid hemorrhage: a systematic review and metaanalysis update. Stroke. 2010; 41(1): e47-52.

PublMed Abstract | Publisher Full Text | F1000 Recommendation

146. F Wong GK, Chan DY, Siu DY, et al:: High-dose simvastatin for aneurysmal subarachnoid hemorrhage: multicenter randomized controlled double-blinded clinical trial. Stroke. 2015; 46(2): 382-8.

PubMed Abstract | Publisher Full Text | F1000 Recommendation

147. F Kirkpatrick PJ, Turner CL, Smith C, et al:: Simvastatin in aneurysmal subarachnoid haemorrhage (STASH): a multicentre randomised phase 3 trial. Lancet Neurol. 2014; 13(7): 666-75.

PubMed Abstract | Publisher Full Text | F1000 Recommendation

148. F Tseng MY, Czosnyka M, Richards $\mathrm{H}$, et al.: Effects of acute treatment with pravastatin on cerebral vasospasm, autoregulation, and delayed ischemic deficits after aneurysmal subarachnoid hemorrhage: a phase II randomized placebo-controlled trial. Stroke. 2005; 36(8): 1627-32.

PubMed Abstract | Publisher Full Text | F1000 Recommendation

149. Suzuki S, Sayama T, Nakamura T, et al.: Cilostazol improves outcome afte subarachnoid hemorrhage: a preliminary report. Cerebrovasc Dis. 2011; 32(1): 89-93.

PubMed Abstract | Publisher Full Text

150. F Niu PP, Yang G, Xing YQ, et al.: Effect of cilostazol in patients with aneurysmal subarachnoid hemorrhage: a systematic review and metaanalysis. J Neurol Sci. 2014; 336(1-2): 146-51.

PubMed Abstract | Publisher Full Text | F1000 Recommendation

151. Senbokuya N, Kinouchi H, Kanemaru K, et al.: Effects of cilostazol on cerebral vasospasm after aneurysmal subarachnoid hemorrhage: a multicenter prospective, randomized, open-label blinded end point trial. J Neurosurg. 2013; 118(1): 121-30.

PubMed Abstract | Publisher Full Text

152. Kimura $\mathrm{H}$, Okamura $\mathrm{Y}, \mathrm{Chiba} \mathrm{Y}$, et al:: Cilostazol administration with combination enteral and parenteral nutrition therapy remarkably improves outcome after subarachnoid hemorrhage. Acta Neurochir Suppl. 2015; 120: 147-52.

PubMed Abstract 


\section{Open Peer Review}

\section{Current Peer Review Status:}

\section{Editorial Note on the Review Process}

Faculty Reviews are review articles written by the prestigious Members of Faculty Opinions. The articles are commissioned and peer reviewed before publication to ensure that the final, published version is comprehensive and accessible. The reviewers who approved the final version are listed with their names and affiliations.

\section{The reviewers who approved this article are:}

\section{Version 1}

\section{Nikolaus Plesnila}

Institute for Stroke and Dementia Research, University of Munich Medical Center, Munich, Germany Competing Interests: No competing interests were disclosed.

\section{Michael N. Diringer}

Neurosurgery, Anesthesiology, and Occupational Therapy, Washington University School of Medicine, St. Louis, MO, USA

Competing Interests: No competing interests were disclosed.

\section{Stephan Mayer} Institute for Critical Care Medicine, Mount Sinai Medical Center, New York, New York, NY, USA Competing Interests: No competing interests were disclosed.

\section{Kyle Pattinson}

Nuffield Department of Clinical Neurosciences, John Radcliffe Hospital, Oxford, UK

Matthew Rowland

Nuffield Department of Clinical Neurosciences, John Radcliffe Hospital, Oxford, UK

Competing Interests: No competing interests were disclosed. 
The benefits of publishing with F1000Research:

- Your article is published within days, with no editorial bias

- You can publish traditional articles, null/negative results, case reports, data notes and more

- The peer review process is transparent and collaborative

- Your article is indexed in PubMed after passing peer review

- Dedicated customer support at every stage

For pre-submission enquiries, contact research@f1000.com 